\title{
Pharmacognostic Study of Leaves of Hedeoma patens
}

\author{
Laura Aracely Contreras-Angulo, Denisse Vega-Gaxiola, Alexis Emus-Medina, Jose Basilio Heredia*
}

\section{Laura Aracely Contreras-Angulo, Denisse Vega-Gaxiola, Alexis Emus-Medina, Jose Basilio Heredia*}

Centro de Investigación en Alimentación y Desarrollo A.C., Carretera a Eldorado Km 5.5 Campo el Diez, Culiacán, Sinaloa, MÉXICO. 80110.

Correspondence

Dr Jose Basilio Heredia

Centro de Investigación en Alimentación y Desarrollo A.C., Carretera a Eldorado Km 5.5 Campo el Diez, Culiacán, Sinaloa, 80110, MÉXICO.

Phone No: +52 667 7605536; Fax +52 6677605537

E-mail: jbheredia@ciad.mx

History

- Submission Date: 26-01-2018;

- Review completed: 16-03-2018

- Accepted Date: 03-05-2018

DOI : 10.5530/pj.2018.5.155

Article Available online http://www.phcogj.com/v10/i5

\section{Copyright}

(C) 2018 Phcog.Net. This is an openaccess article distributed under the terms of the Creative Commons Attribution 4.0 International license.

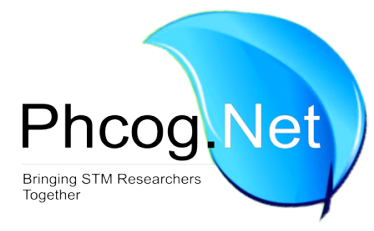

\begin{abstract}
Introduction: Oregano is a plant consumed as a spice and used to a lesser extent as a medicinal plant for the treatment of respiratory and stomach diseases, among others. Oregano is made up of a large number of species and is currently under study for its antimicrobial, antioxidant, anti-inflammatory and hypoglycemic properties. However, pharmacognostic studies of some wild species are lacking. Methods: The present research aims to identify taxonomically and to evaluate the morphological characteristics of Hedeoma patens, a plant used as oregano in Mexico. Results: The specimens were identified as Hedeoma patens $\mathrm{J}$. and their main morphological features were trichome-pelted sites for synthesis of essential oils. Conclusion: The plant used in Badiraguato, Sinaloa is Hedeoma patens $\mathrm{J}$. and the structures that synthesize phenolic compounds and essential oils could suggest a potential use of this plant and will form a basis for future research.

Key words: Essential oils, Bioactives, Hedeomapatens J, Oregano, Pharmacognostic, Chemical/
\end{abstract} Nutraceutical Industries.

\section{INTRODUCTION}

Oregano is an aromatic plant, its name derives from the Greek language "oros" (mountain) and "ganos" (ornament) "adornment or joy of the mountain", because its appearance and aroma is used since ancient times as a spice in the culinary art and as Medicinal plant, various cultures used as an infusion against respiratory and stomach diseases, and its essential oil as a wound disinfectant, are currently attributed antimicrobial, antioxidant, anti-inflammatory and hypoglycemic effects, important properties in the prevention and treatment of chronic degenerative diseases, so their study has increased in recent years. ${ }^{1-4}$ Oregano (Origanum vulgare) is represented worldwide mainly by two genera: Origanum (Lamiaceae) native to Europe and Lippia (Verbenaceae) native to America. In Mexico, oregano is found in regions of tropical climates, arid and semi-arid temperate, is distributed wild in at least 24 entities located in the central, western and northern areas of the country, however, its cultivation is traditional and limited. To date, 40 species belonging to four families have been identified: Lippia spp., Lippia berlandieri Schauer, Lippia palmeri Wast and Lippia graveolens $\mathrm{H}^{4,5}$ Its main habitats are generally rocky soils of hills, slopes and glens in altitudes of 400 to 2000 masl, being in greater abundance in altitudes of 1400 and 1800 masl, ${ }^{4}$ Such is the case of the town of Surutato (altitude of 1614 masl), Badiraguato, Sinaloa, Mexico where there is a wild plant material that traditionally the people of those places have used as a condiment since it has sensory characteristics similar to other Oregano species. Therefore, the objective of this study was to identify to which species belongs the wild oregano found in Surutato, Sinaloa, Mexico.

\section{MATERIALS AND METHODS}

\section{Sampling area}

The harvest of plants was carried out in the flowering stage (September), and the place was located with GPS in the town of Surutato, located in the Sierra Madre Occidental with coordinates N 25 ${ }^{\circ} 51^{\prime}$ $6.2^{\prime \prime}$, W $107^{\circ} 3456.6^{\prime \prime}$ at an altitude of 1614 masl in Sinaloa, Mexico.

\section{Taxonomic identification and confirmation}

Plant material was wrapped in newspaper and mounted on a wooden grate manual press, then dried in a commercial dehydrator at $40^{\circ} \mathrm{C}$ (Excalibur Co, Sacramento, CA, USA) for 24 h. ${ }^{6}$ After drying the sample, the specimens of herbarium were prepared. The species were identified and confirmed by the botanical researcher Rito Vega-Aviña from the herbarium "Jesus Gonzalez-Ortega" located at the Agricultural School of the Sinaloa State University.

\section{Microscopic analysis}

The microscopic examination consisted in making freehand cuts of the fresh material, to observe in a stereoscope the anatomy of the flower. For the epidermal analysis, the epidermis was detached from the living material, rinsed with distilled water and placed on slides for observation in an Axiophot model, Carl Zeiss microscope (Thornwood, NY, 
USA). For the identification of the cellular structures of mature leaves and stems, an anatomical observation of the tissues included in paraffin was made, for which the tissues were prepared in small sections, which were fixed with an FAA solution (formaldehyde, ethyl alcohol, and acetic acid, in proportion 3:1:1); The classical techniques of dehydration, paraffin inclusion, microtomes from 10 to $14 \mathrm{~mm}$, double staining and subsequent assembly with Canada balsam were applied. Finally, photomicrographs were taken an Axiophot model, Carl Zeiss microscope (Thornwood, NY, USA).

\section{RESULTS AND DISCUSSION}

\section{Identification and confirmation of taxonomy}

The six specimens were identified and taxonomically classified by Rito Vega-Acuña from the herbarium "Jesus Gonzalez-Ortega" located at the Agricultural School of the Sinaloa State University. These specimens were identified as Hedeoma patens J. These results agreed with those reported by Vega-Aviña, ${ }^{7}$ as compared with those from the list of existing flora in the state of Sinaloa. The genus Hedeoma comes from the Greek "hedys" (sweet) and "osme" (odor), an ancient name for a strongly aromatic, sweet-smelling mint. It is a genus of 42 American species, which are distributed from southern Canada to Central and South America. In Mexico, there are 29 endemic species. Irving ${ }^{8}$ divided it into 4 subgenres, 3 of which exist in Mexico (Ciliatum, Poliominthoides and Saturejoides) and describes the genus Hedeoma as herbaceous, annual or perennial plants, with the calyx tube usually gibbous at the base; Close to Poliomintha and Hesperozygis. On the other hand, Rzedowski and Rzedowski ${ }^{9}$ suggest that plants of the genus Hedeoma are low and generally aromatic, sometimes sub-shrub; stems branched, ascending or decumbent, pubescent at the top; small leaves and petioles, ovate, elliptic or rhombic-lanceolate, whole or serrulate; lilac or whitish flowers with purplish tints usually grouped in laxos, axillary verticils, of few flowers that form pseudo clusters or terminal spastros; tubular calyx, usually somewhat gibbous at the base, 5-dentate or bilobed, with hairy throat inside; bilabial corolla, infundibuliforme tube, of the same size of the calyx; two fertile stamens, a rudimentary or absent upper pair, bilocular anthers; ovoid and smooth mericarp.

\section{Morphological description}

The physical characteristics of the plant identified as Hedeoma patens J. observed in the leaf presented small elliptical form $(1-2.3 \mathrm{~cm})$ long and wide $(5-8 \mathrm{~mm})$. Also main veins were observed (Figure 1A), bilabial flower with 2 stamens, and a pink corolla with violet touches (Figure 1B). A gibbous chalice was seen in the transverse section (Figure 1C), and a tetralocular ovary was observed and in the longitudinal section (Figure 1D). Also, mature mericarps were observed. These observations agree with the morphological characteristics reported for the genus Hedeoma. ${ }^{8,9}$

\section{Macroscopic and microscopic analysis}

In the observations made by microscope, the phloem was identified (Figure 2F), which is a structure of transport of substances of low molecular weight mostly sugars, and the xylem (Figure 2F) that transports the water that ascends by the stem towards the leaves and through vessels that can have a length between 20 and $700 \mu \mathrm{m}$, depending on plant's species. Epidermal cells were also identified (Figure $2 \mathrm{H}$ ) which have as a main function to give support and protection to the leaves. In the same way, stomas were observed (Figure 2I), these pores located on the leaf surface allow gas exchange; despite they are more abundant in the leaves they are also found in other green tissues such as stems, fruits, and flowers. One of the most important characteristics observed were the glandular trichomes (Figure 2J), which are typical of aromatic plants and known as a reservoir of lipids. In their structures, there are no defined subcuticular

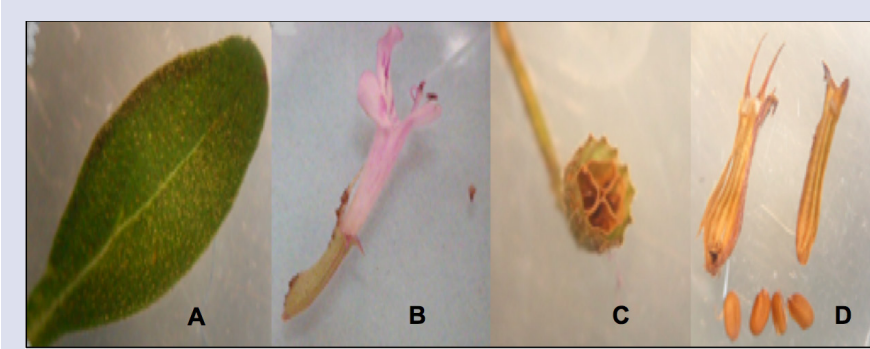

Figure 1: Morphological characteristics of the leaf (A), flower (B), Calyx cross section (C) and Calyx longitudinal cut (D).

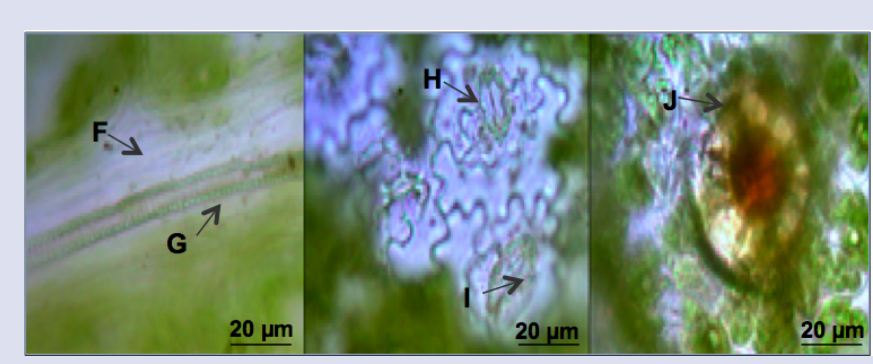

Figure 2: Anatomical structures of the leaf phloem (F), xylem (G), epidermal cell $(\mathrm{H})$, stoma $(\mathrm{I})$ and trichome $(\mathrm{J})$.

spaces, and all the lipid content accumulates within itself which is then eliminated subsequently through cuticular pores ${ }^{10}$

\section{Glandular trichomes}

The trichomes are unicellular or multicellular structures from the epidermal cells and are found on the surface of several organs. ${ }^{11}$ Nonglandular trichomes can be found involved in plant defense, and glandular trichomes that act as organs of secretion of essential oils. ${ }^{12}$ For the observation of the trichomes in the plants, a transverse cut was made to the leaf tissue of $H$. patens $\mathrm{J}$ included in paraffin, and pelleted trichomes were observed with the 10x (Figure 3A) and 40x (Figure 3B) objectives. Pelleted trichomes are considered as the primary site of the biosynthesis of essential oils in Lamiaceae. ${ }^{13}$ In Hedeoma patens J, 3-4 trichomes were found per field, surrounded by numerous chloroplasts. Studies performed on Mentha peribasal epidermal cells showed these cells with slightly more cutinized walls than the remaining tissue. According to Gavalas et al. ${ }^{2}$ peribasal epidermal cells act as an adjuvant of secretory function by transporting the products of photosynthesis from the mesophyll to the cells of the cabezuela. On the other hand, studies in leaves of Hedeoma multiflora showed pelted glandular trichomes distributed around epithelial cells. ${ }^{14}$ In Origanum dictamnus, the cutinization of the lateral walls of the cells was observed, which contributes to a better support when the volume of the tricoma increases during the formation of the subcuticular space, ${ }^{11}$ this cutinization would also act as a barrier to prevent intercellular movement of the secretion. ${ }^{15}$

\section{Protective trichomes}

In the leaves of $H$. patens J. unicellular trichomes were observed (Figure 4A and $4 \mathrm{~B}$ ) where they are seen surrounded by small black spots called warts. In Mentha spicata unicellular trichomes have been observed, the cell walls are ornamented with notable, tenuous or lacking warts. They are observed in leaves and stems. The proximal cell may have a wedge or trapezium shape. ${ }^{16}$ Studies in Hedeoma multiflora showed non-glandular pluricellural trichomes (1-2 cells) with walls decorated with waxy 


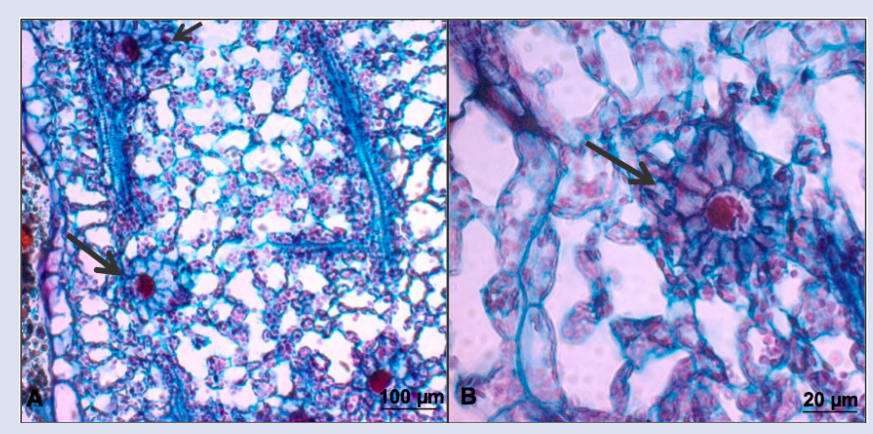

Figure 3: Micrographs of leaves of Hedeoma patens J. with longitudinal cuts ( $\mathrm{A}$ y $\mathrm{B}$ ) arrows indicate the pelted trichomes.

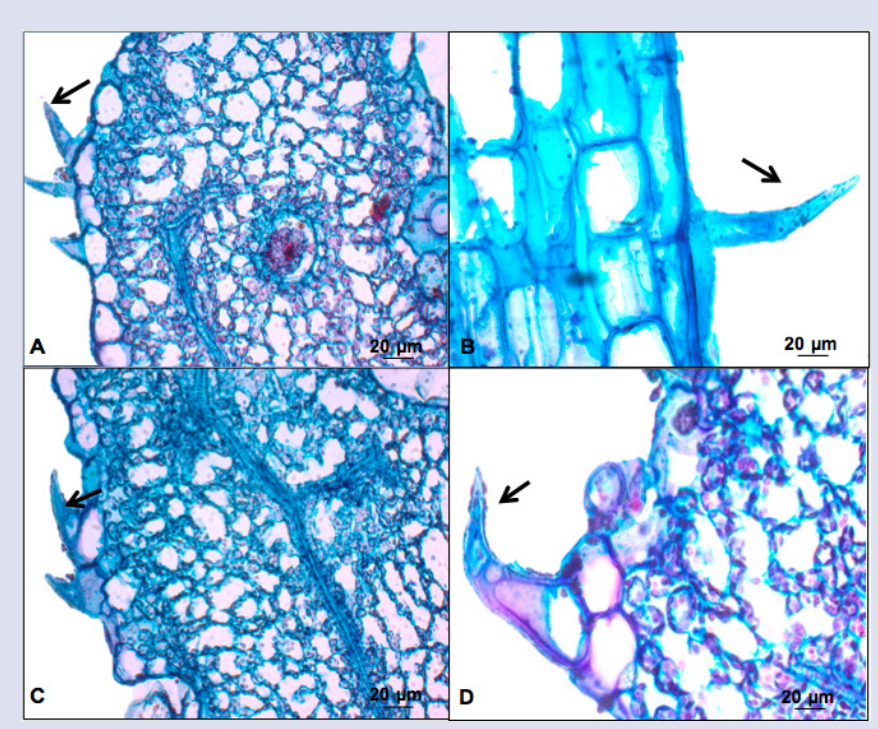

Figure 4: Micrographs of cross sections in leaves of Hedeoma patens $\mathrm{J}$. , the arrows show the structures of unicellular trichomes (A and B) and multicellular (C and D).

papillae. ${ }^{14}$ Multicellular trichomes were also observed (Figure $4 \mathrm{C}$ and 4D) in the leaves of $H$. patens J. located on the outside of the leaves. The protective trichomes are derived from epidermal cells that can be lengthened to form unicellular trichomes (Figure 4) and sometimes divide by mitosis to form multicellular trichomes. ${ }^{17}$

\section{CONCLUSION}

The taxonomic classification of the wild oregano of Surutato, Badiraguato, Sinaloa was Hedeoma patens J. according to the structural found characteristics. In addition, both non-glandular and glandular trichomes were found within the latter, where pellet glandular trichomes were located where phenolic compounds and essential oils are synthesized, which gives this species an economic potential in obtaining these compounds.

\section{ACKNOWLEDGEMENT}

We thank CONACYT for funding the Project: Ciencia Basica No. 252416.

\section{CONFLICT OF INTEREST}

Authors declare no conflict on interest.

\section{ABBREVIATIONS}

J: Jones; SPP: Species; MASL: meters above sea level; GPS: global position system; N: north; W: west; FAA: formaldehyde, alcohol and acetic acid.

\section{REFERENCES}

1. Singletary K. Oregano: overview of the literature on health benefits. Nutrition Today. 2010;45(3):129-38.

2. Gavalas N, Bosabalidis A, Kokkini S. Comparative study of leaf anatomy and essential oils of the hybrid Mentha $x$ villoso-nervata and its parental species M. Iongifolia and M. spicata. Israel Journal of Plant Sciences. 1998;46(1):27-33.

3. Muñoz Centeno LM. Plantas medicinales españolas: Origanum vulgare L.(Lamiaceae)(orégano). Acta Botanica Malacitana. 2002;27:273-80.

4. Aguilar-Murillo X, Valle-Meza G, González-Rosales G, Murillo-Amador B. Guía De Cultivo De Orégano. Centro de Investigaciones Biológicas del Noroeste, SC La Paz, Baja California Sur, México. 2013:106.

5. García-Pérez E, Fernando Francisco C-Á, Gutiérrez-Uribe JA, García-Lara S Revisión de la producción, composición fitoquímica y propiedades nutracéuticas del orégano mexicano. Revista mexicana de ciencias agrícolas. 2012;3(2):339-53.

6. Licina BZ, Stefanovic OD, Vasic SM, Radojevic ID, Dekic MS, Comic LR. Biological activities of the extracts from wild growing Origanum vulgare L. Food control. 2013;33(2):498-504

7. Vega Aviña R. Catálogo flybase de datos preliminar de la flora de Sinaloa. Universidad Autónoma de Sinaloa Facultad de Agronomía Informe final SNIBCONABIO proyecto. 2000(L057).

8. Irving RS. The systematics of Hedeoma (Labiatae). Sida. 1980;8(3):218-95.

9. Rzedowski G, Rzedowski J. Flora fanerogámica del Valle de México, Instituto de Ecología y Comisión Nacional para el Conocimiento y Uso de la Biodiversidad. Pátzcuaro, Michoacán, México. 2001.

10. Azcon B, Talón M. Fundamentos de fisiología vegetal. 2a . McGraw-Hill. México, DF. 2003.

11. Bosabalidis AM, Tsekos I. Glandular hair formation in Origanum species. Annals of Botany. 1984;53(4):559-63.

12. Shafiee-Hajiabad M, Hardt M, Honermeier B. Comparative investigation about the trichome morphology of Common oregano (Origanum vulgare L. subsp. vulgare) and Greek oregano (Origanum vulgare L. subsp. hirtum). Journal of Applied Research on Medicinal and Aromatic Plants. 2014;1(2):50-8.

13. Gershenzon J, Maffei M, Croteau R. Biochemical and histochemical localization of monoterpene biosynthesis in the glandular trichomes of spearmint (Mentha spicata). Plant Physiology. 1989;89(4):1351-7.

14. Novoa MC, Monti C, Vizcaíno CE. Anatomia y etnobotanica de cuatro especies de Labiateae de la provincia biogeografica pampeana, usadas en la medicina popular. acta farmacéutica bonaerense. 2005;24(4):512.

15. Gersbach PV. The essential oil secretory structures of Prostanthera ovalifolia (Lamiaceae). Annals of Botany. 2002;89(3):255-60.

16. Bonzani N, Espinar LA. Estudios anatómicos de tres especies de Lamiaceae usadas en medicina popular. Acta Farm Bonaerense. 1993;12(3):113-23.

17. Fahn A. Structure and function of secretory cells. Advances in botanical research. 2000;31:37-75.

Cite this article: Contreras-Angulo LA, Vega-Gaxiola D, Emus-Medina A, Heredia JB. TPharmacognostic Study of Leaves of Hedeoma patens. Pharmacog J. 2018;10(5):921-4. 


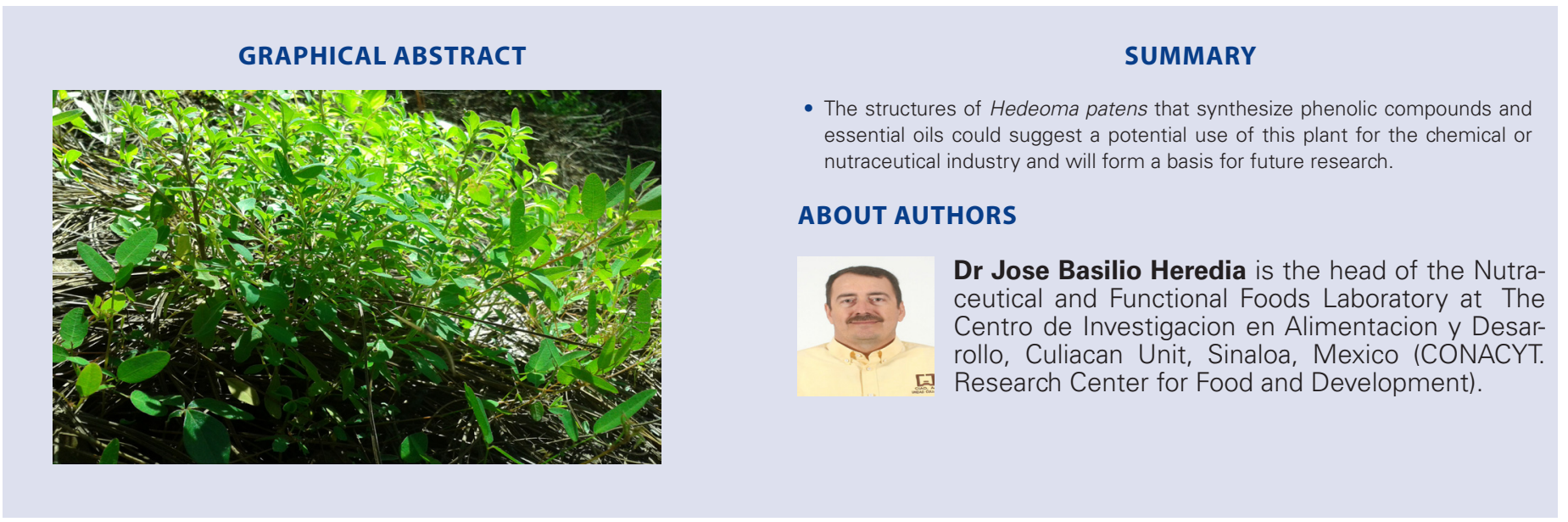

